\title{
Effectiveness of Geoelectrical Resistivity Surveys for the Detection of a Debris Flow Causative Water Conducting Zone at KM 9, Gap-Fraser's Hill Road (FT 148), Fraser's Hill, Pahang, Malaysia
}

\author{
Mohamad Anuri Ghazali, ${ }^{1}$ Abd Ghani Rafek, ${ }^{1}$ \\ Kadderi Md Desa, ${ }^{1}$ and Suhaimi Jamaluddin ${ }^{2}$ \\ ${ }^{1}$ School of Environmental Sciences and Natural, Faculty of Science Technology, Universiti Kebangsaan Malaysia, Selangor, \\ 43600 Bangi, Malaysia \\ ${ }^{2}$ Slope Engineering Branch, Public Works Department, Jalan Sultan Salahuddin, 50582 Kuala Lumpur, Malaysia \\ Correspondence should be addressed to Abd Ghani Rafek; aghani@ukm.my
}

Received 14 September 2012; Revised 13 November 2012; Accepted 14 November 2012

Academic Editor: Karoly Nemeth

Copyright (C) 2013 Mohamad Anuri Ghazali et al. This is an open access article distributed under the Creative Commons Attribution License, which permits unrestricted use, distribution, and reproduction in any medium, provided the original work is properly cited.

\begin{abstract}
This study reports the findings of resistivity surveys which were conducted at the initiation area of debris flow at KM 9, Fraser's Hill Gap road (FT148). The study involves three slope parallel survey lines and two lines perpendicular to the slope face. The parallel lines are FH01, FH02, and FH03, while the lines FH04 and FH05 are perpendicular. A granite body was detected at the central part of the east line and is nearest to the ground surface along FH02. The existence of low resistivity zones within the granite body is interpreted as highly fractured, water conducting zones. These zones are continuous as they have been detected in both the eastwest as well as the north-south lines. The residual soil layer is relatively thin at zones where weathered granite dominates the slope face of the failure mass. The weak layer is relatively thick with an estimated thickness of $80 \mathrm{~m}$ and water flow occurs at the base of it. The high water flow recorded from the horizontal drains further supports the possible existence of these highly fractured, water conducting zones located within the granite. The shallow fractured granite is virtually "floating" above the water saturated zone and therefore is considered unstable.
\end{abstract}

\section{Introduction}

The study area has experienced at least four debris flow incidents, which are concentrated at an initiation zone. One of the debris flow triggering factors in the mountainous terrain of Peninsular Malaysia is high intensity rainfall during or before the debris flow incident. At the time of occurrence of the debris flows in the study area, the intensity of rainfall recorded was between $0 \mathrm{~mm} /$ day to $14 \mathrm{~mm} /$ day. This value is not considered high for Malaysian condition. The finding is based on the current larger study on seven other sites in Peninsular Malaysia which showed that heavy rainfall is a major triggering factor. However, a Fraser Hill site, incidents of debris flow occurred during low of rainfall intensity and at the same time high water flow was observed. Therefore, the source of this water flow needed to be established.

A debris flow is one type of the natural disasters that can be classified as landslides and can cause damage to property and loss of life. The first definition of debris flow was highlighted by Stiny as a flood of mountain torrents, carrying suspended load and transporting quantities of bedload [1]. Sharpe defined debris flow as a rapid flow of saturated or viscous debris in a stream or channel [2]. According to Hungr et al. a debris flow is defined as a very rapid to extremely rapid flow of saturated nonplastic debris in a steep channel $[3,4]$. The debris is loose unsorted material of low plasticity such as that produced by mass wasting processes (colluvium), weathering (residual soil), glacial transport 


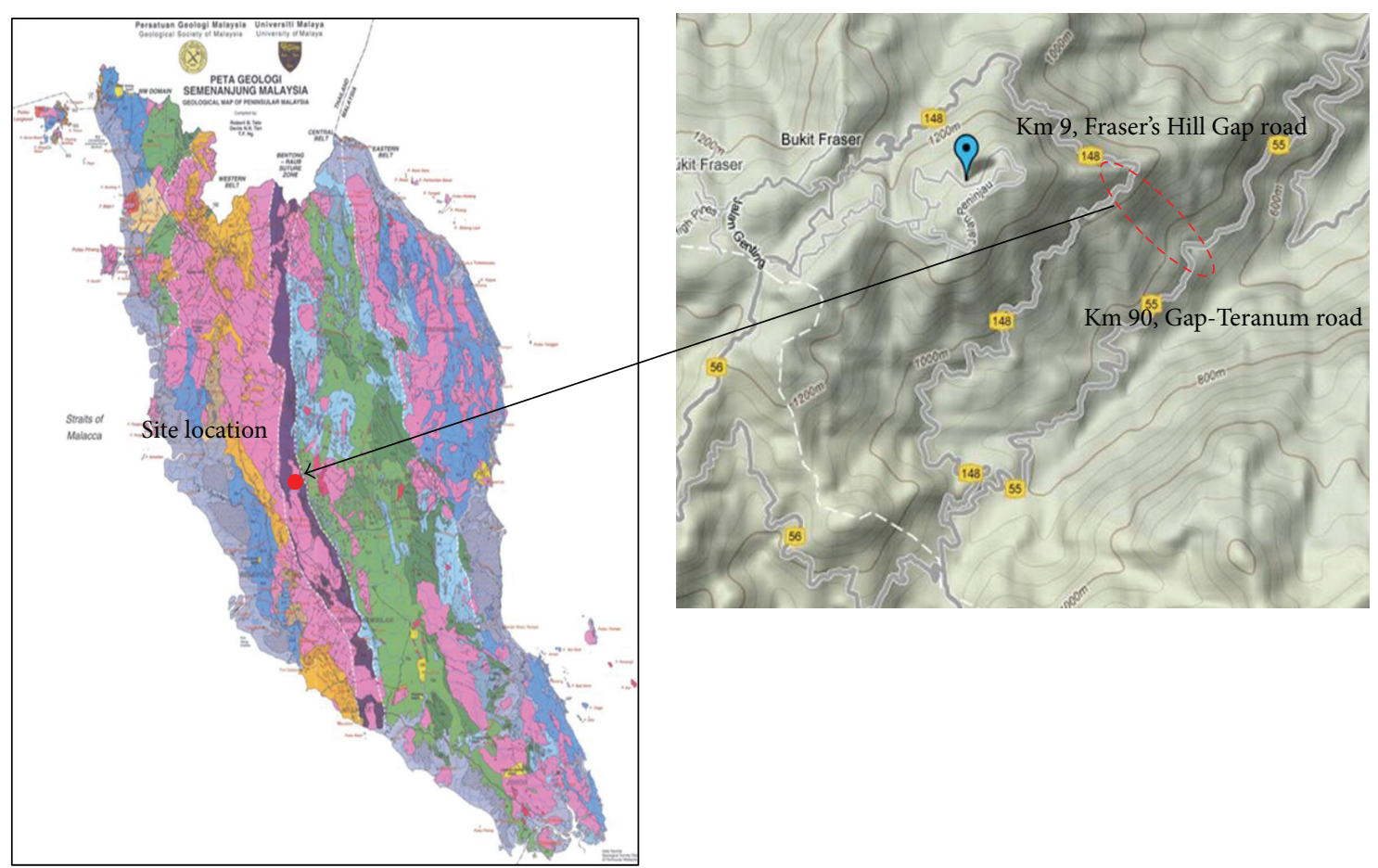

FIGURE 1: Location of the study area on the geological map of Peninsular Malaysia, with Google image of site area [7].

(till or ice contact deposits), explosive volcanism (granular pyroclastic deposits), or human activity (e.g., mine spoil). Meanwhile, Jakob, considered "sources of debris" to include soil blankets and veneers on steep slopes, colluvial gully fills, channel bedload material, zones of weathered or altered rocks, residual soil, headwalls and side slopes of steep gullies, talus deposits, man-made fills, and similar accumulations of unstable or erodible material [5]. Meanwhile, Iverson focuses on widespread Coulomb failure within a sloping soil, rock or sediment mass, pore-fluid pressures, and conversion of landslide translational at debris source zones [6].

Chiessi et al., showed that geoelectrical imaging can be employed to confirm the variability of the characteristics of both the cover material and the substratum, a variability which is also highlighted in seismic surveys by lateral variations in velocity within the same layer [8]. Jongman and Garambois used the geoelectrical resistivity to determine the location of the vertical and lateral boundaries of the slide debris and detection of water within the slide debris [9].

Determination of groundwater flow has been reviewed by Hubbard and Linde by combining Ground Penetration Radar (GPR) with seismic survey and geoelectrical resistivity survey [10]. Results from the application of geophysical methods available, the case studies illustrate the use of hydrogeophysical approaches to quantity subsurface architecture that influence flow (such as hydrostratigraphy and preferential pathways), delineate anomalous subsurface fluid bodies (such contaminant plumes), monitor hydrological process (such as freshwater-seawater interface dynamics and flow through fractures), and estimate hydrological properties (such as hydraulic conductivity) and state variables (such as water content).
In addition, boreholes could also be used to determine the soil properties and identify type of material and strength of the soil. The combination of these methods is very effective and costly. Unfortunately, boreholes could not to be carried out at the study site because drilling rigs are unable to access the extremely hilly terrain.

The main purpose of this study is to determine the weak layer at the initiation zone using geoelectrical resistivity imaging.

1.1. Objective. Generally the scope of this work is to understand factors associated with debris flow incidents in Peninsular Malaysia. The main objective of this specific study was to determine the main cause of the formation of the debris flow mass within the initiation zone. The existence of a high outflow of water at the toe of the slope suggested the possible existence of weak zones that are water conducting. Therefore geoelectrical resistivity imaging was applied to identify

(a) zones of soil or weathered rock with high water content,

(b) groundwater flow,

(c) weak zones of weathered and highly fractured rocks.

\section{Background}

The study area is located at $\mathrm{km} \mathrm{9,} \mathrm{Gap-Fraser's} \mathrm{Hill} \mathrm{road}$ (FT148), and within the Raub-Bentong Suture zone as shown on the geological map of Peninsular Malaysia (Figure 1). Landslides into the channel at this location occurred repeatedly resulting in debris flow impacts to the Gap-Tranum 
TABLE 1: (a) Chronology of landslides at km 9, Fraser's Hill-Gap road (FT148). (b) Chronology of debris flows at km 90, Gap-Tranum road (FT 55).

(a)

\begin{tabular}{ll}
\hline Date & Description \\
\hline (a) December 16,2007 & $\begin{array}{l}\text { A landslide occurred at Kilometre 4-5, FT 148, New Gap road to Fraser's Hill and the road was declared unsafe } \\
\text { for all vehicles }\end{array}$ \\
\hline (b) January 12,2009 & $\begin{array}{l}\text { The collapse of a new embankment occurred within the project site, causing some damage to equipment and } \\
\text { machinery and affected work in progress (Figure 18: photograph taken on January 19 2008 and Figure 19: view } \\
\text { final landslide before remediation) }\end{array}$ \\
\hline
\end{tabular}

(b)

Date Description

(a) November 16, 2007 Blockage occurred due to rubble, mud, and rock slide material. Public Work Department (PWD) carried out cleaning work and the road was eventually opened

(b) February 27, 2008 Debris flow occurred again, resulting in the blockage due to mud, rock slides, and rock blocks. Road was closed to all traffic users from $03 / 03 / 2008$ to $06 / 06 / 2008$.

(c) March 6, $2008 \quad$ Clearing work carried out using explosives

(d) March 7, $2008 \quad$ Route was reopened to all traffic

(e) March 8, $2008 \quad$ Debris flow occurred again and caused the flow of mud and boulders to cover the road. Cleaning work carried out and the road could be used by light vehicles

(f) March 15, $2008 \quad$ Debris flow occurred with debris, boulders, and mud. Cleaning work carried out and road was opened to light vehicles only

(g) March 17, $2008 \quad$ Debris flow occurred. Cleaning work carried out and road was opened to light vehicles only

(h) March 19, 2008 Debris flow occurred resulting in mud and rock slides. The road was closed. Cleaning could not be conducted

(i) March 22, $2008 \quad$ Bridge collapsed causing structural breaks of the steel plate beam buckle

(j) March 23, 2008 Debris flow and the cliff road failed and the road surface collapsed for over $60 \mathrm{~m}$ (Figure 3 shows this incident)

(k) June 26, $2008 \quad$ Repairs completed and roads opened to vehicles

(l) July 3, $2008 \quad$ The collapse of new gabion retaining wall, destroyed by rock slides

(m) July 8, $2008 \quad$ New debris flow resulting in mudslide. Road was closed

(n) July 15, $2008 \quad$ Cleaning works carried out. Road reopened to all vehicles

road (FT 55). Repeated failures occurring at km 9, GapFraser's Hill road (FT148), with debris flow were documented on December 16, 2007 and January 12, 2008 and several subsequent incidents which were not recorded. This study location is the source of the debris flow formation down the channel that impacted the Tranum-Gap road at km 90, FT 55 (see Figure 2 for a simplified site location map). The landslides occurred could be classified as regressive landslide of large scale. The chronology of events at both roads is documented in Tables 1(a) and 1(b).

\section{Physiographic and Geologic Setting}

The granitic bedrock at Fraser's Hill is a part of the Titiwangsa Mountain Range. The porphyritic granite of the study area is moderate to coarse grain and crossed by the Kuala Lumpur and Bukit Tinggi faults [12]. This area consists of porphyritic granite, biotite granite, and sheared granite (protomilonite, ortomilonite, and ultramilonite) [12]. The distance between the initiation area ( $\mathrm{km} \mathrm{9,} \mathrm{Gap-Fraser's} \mathrm{Hill} \mathrm{road)} \mathrm{of} \mathrm{debris}$ flow to the impact area (km 90, Gap-Teranum road) is about $1260 \mathrm{~m}$. Meanwhile, the catchment area at this location is $0.4 \mathrm{~km}^{2}$.

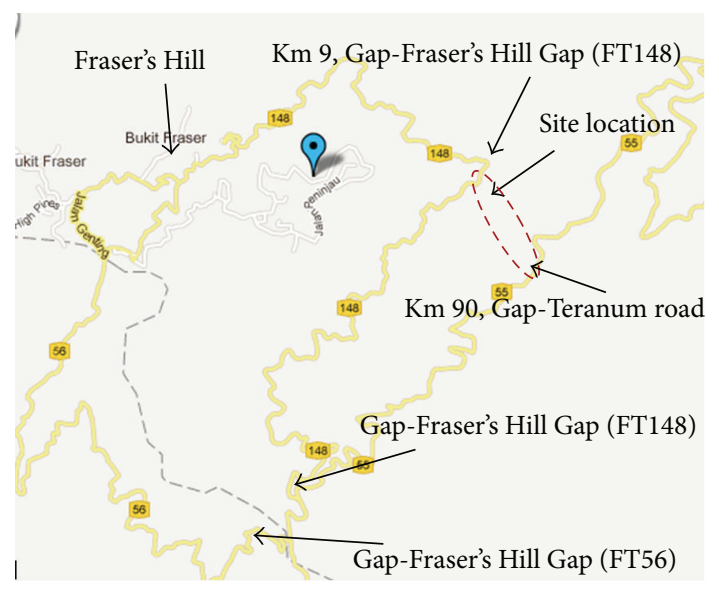

Figure 2: Simplified site location map.

There are two main streams flowing down to the impact zone of debris flow. The highest peak is Bukit Peninjua with an elevation of $1500 \mathrm{~m}$. Overall the stream bed gradient is $39.3^{\circ}$ and the average slope angle of the banks is $40^{\circ}$ to $48^{\circ}$. The outcrop of the formation of the debris flow is weathered 
TABLE 2: The main coordinates of the resistivity lines.

\begin{tabular}{|c|c|c|c|}
\hline Name of resistivity line & Location of first electrode (A) & Location of last electrode (B) & Location of center of line (C) \\
\hline \multirow{2}{*}{ FH01 } & $\mathrm{N} 3^{\circ} 42^{\prime} 58.0^{\prime \prime}$ & $\mathrm{N} 3^{\circ} 42^{\prime} 58.1^{\prime \prime}$ & $\mathrm{N} 3^{\circ} 42^{\prime} 58.4^{\prime \prime}$ \\
\hline & $\mathrm{E} 101^{\circ} 45^{\prime} 28.5^{\prime \prime}$ & $\mathrm{E} 101^{\circ} 45^{\prime} 31.8^{\prime \prime}$ & $\mathrm{E} 101^{\circ} 45^{\prime} 30.3^{\prime \prime}$ \\
\hline \multirow{2}{*}{ FH02 } & $\mathrm{N} 3^{\circ} 42^{\prime} 57.9^{\prime \prime}$ & $\mathrm{N} 3^{\circ} 42^{\prime} 58.7^{\prime \prime}$ & $\mathrm{N} 3^{\circ} 42^{\prime} 59.5^{\prime \prime}$ \\
\hline & $\mathrm{E} 101^{\circ} 45^{\prime} 31.5^{\prime \prime}$ & $\mathrm{E} 101^{\circ} 45^{\prime} 28.7^{\prime \prime}$ & $\mathrm{E} 101^{\circ} 45^{\prime} 30.0^{\prime \prime}$ \\
\hline \multirow{2}{*}{ FH03 } & $\mathrm{N} 3^{\circ} 43^{\prime} 02.3^{\prime \prime}$ & $\mathrm{N} 3^{\circ} 42^{\prime} 58.6^{\prime \prime}$ & $\mathrm{N} 3^{\circ} 43^{\prime} 00.2^{\prime \prime}$ \\
\hline & $\mathrm{E} 101^{\circ} 45^{\prime} 32.0^{\prime \prime}$ & $\mathrm{E} 101^{\circ} 45^{\prime} 27.1^{\prime \prime}$ & $\mathrm{E} 101^{\circ} 45^{\prime} 30.2^{\prime \prime}$ \\
\hline \multirow{2}{*}{ FH04 } & $\mathrm{N} 3^{\circ} 43^{\prime} 02.7^{\prime \prime}$ & $\mathrm{N} 3^{\circ} 42^{\prime} 58.2^{\prime \prime}$ & $\mathrm{N} 3^{\circ} 43^{\prime} 00.8^{\prime \prime}$ \\
\hline & $\mathrm{E} 101^{\circ} 45^{\prime} 30.7^{\prime \prime}$ & $\mathrm{E} 101^{\circ} 45^{\prime} 35.4^{\prime \prime}$ & $\mathrm{E} 101^{\circ} 45^{\prime} 33.3^{\prime \prime}$ \\
\hline \multirow{2}{*}{ FH05 } & $\mathrm{N} 3^{\circ} 43^{\prime} 01.6^{\prime \prime}$ & $\mathrm{N} 3^{\circ} 42^{\prime} 57.4^{\prime \prime}$ & $\mathrm{N} 3^{\circ} 42^{\prime} 59.2^{\prime \prime}$ \\
\hline & $\mathrm{E} 101^{\circ} 45^{\prime} 26.7^{\prime \prime}$ & $\mathrm{E} 101^{\circ} 45^{\prime} 29.4^{\prime \prime}$ & $\mathrm{E} 101^{\circ} 45^{\prime} 27.7^{\prime \prime}$ \\
\hline
\end{tabular}

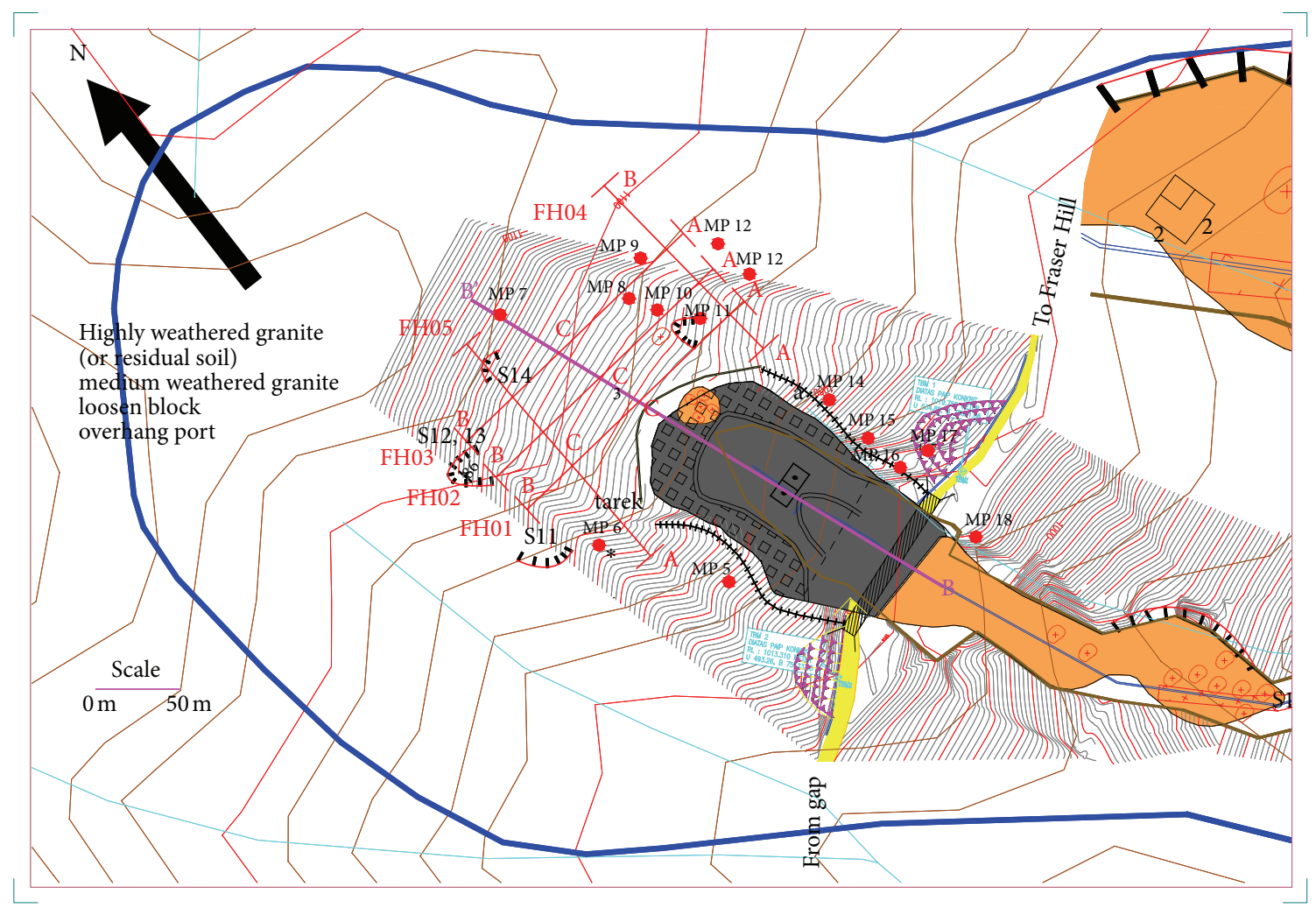

MP 5-Mackintosh Probe

FH01-resistivity line

FIgURE 3: Location of geoelectrical resistivity lines and Mackintosh Probe at initiation area.

granite with weathering grades between IV to $\mathrm{V}$ as well as residual soil. There are also blocks of granite boulders loosely suspended within the failure mass.

Figure 3 below shows the location of five 200 meter resistivity lines. Three resistivity lines are named as FH01, $\mathrm{FH} 02$, and FH03 which are parallel to each other and spaced $25 \mathrm{~m}$ apart. The other two-lines FH04 and FH05 are spaced $100 \mathrm{~m}$ a part in north-south direction and are perpendicular to the above FH01, FH02, and FH03 lines (Table 2).

\section{Materials and Methodology}

4.1. Resistivity Survey. The method employed in this study is the standard method using Wenner array with resistivity line parallel and perpendicular to the slope face. The Wenner array with a total profile length of $200 \mathrm{~m}$ was employed with an estimated penetration depth of $20 \mathrm{~m}$ to $30 \mathrm{~m}$ below the ground surface. Zones of high water content and weak zones could be determined as low resistivity zones by using this 


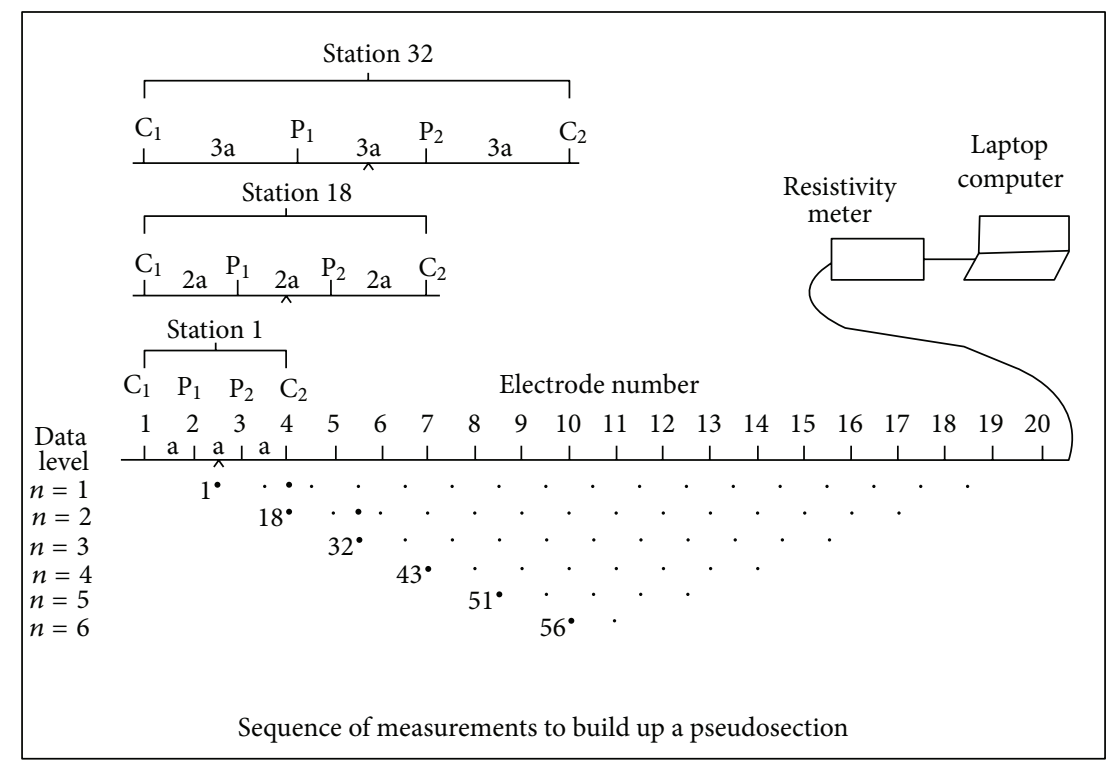

FIGURE 4: The arrangement of electrodes for a 2D electrical survey and the sequence of measurements used to build up a pseudosection [11].

method. Refraction for seismic survey could not be used due to the limited space for seismic lines compared to the estimated target depth.

To determine the true subsurface resistivity, an inversion of the measured apparent resistivity values using a computer program was carried out.

One of the new developments in recent years is the use of $2 \mathrm{D}$ geoelectrical resistivity imaging or tomography surveys to map areas with moderately complex geology [11].

Such surveys are usually carried out using a large number of electrodes connected to a multicore cable. A modern resistivity meter together with an electrode selector system is used to automatically select the relevant four electrodes for each measurement.

Figure 4 shows the typical setup for a $2 \mathrm{D}$ survey with a number of electrodes along a straight line attached to a multicore cable. Normally a constant spacing between adjacent electrodes is used. The multi-core cable is attached to an electronic switching unit which is connected to a resistivity meter or terrameter.

The sequence of measurements to take, the type of array to use, and other survey parameters (such the current to use) are normally entered into a text file which can be read by a built-in computer program in the resistivity meter or terrameter. After reading the control file, the computer program then automatically selects the appropriate electrodes for each measurement.

The terrameter or resistivity meter employed was an ABEM SAS1000 and ABEM LUND ES464 electrode selector system. This system is connected to 41 stainless steel electrodes, which are laid out in a straight line with a constant spacing via a multi-core cable (Figures 4 and 22). The resistivity meter selects only four active electrodes to be used for each measurement.

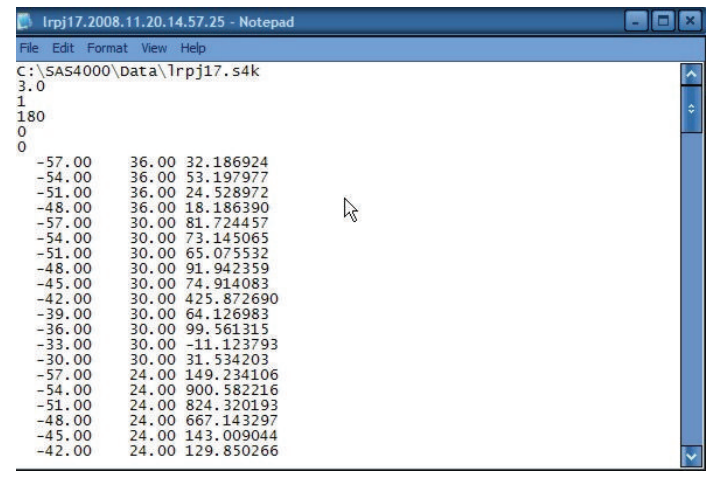

FIGURE 5: Notepad window for correction of data.

4.2. Data Processing. Resistivity data was analyzed using a driven software RES2DINV Ver .3.54 (see Figure 9) with nine usual options at the top of the screen (file, edit, change settings, inversion, display, topography options, print, help, and quit). The input data file must be in a "file. Dat" format. The procedures below were steps followed during the processing of resistivity data using the RES2DINV software.

(a) Selected data file from read menu.

(b) Exterminated bad datum points from Edit menu. A negative value or values which were too large were edited using notepad or other text editor (Figure 5). A Function to exterminate bad datum points was used to eliminate further bad data value by clicking the mouse when the cursor at the points of those was not in line (Figure 6).

(c) Change menu was also used to modify the resistivity data by selecting the number of iterations of required 


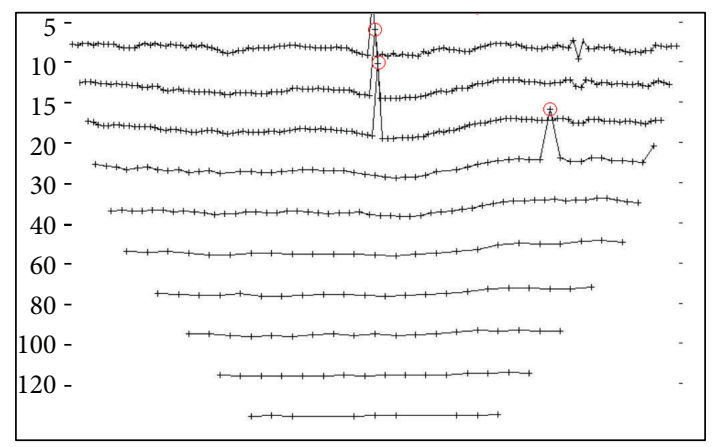

Figure 6: Procedure to remove bad data points. Red circles are data points removed.

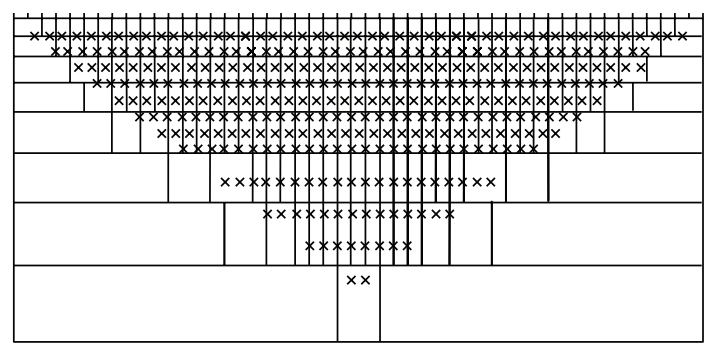

Datum block

$\times \quad$ Level block

FIGURE 7: Blocks datum and datum level rectangular building blocks to produce the geological model.

while the damping factor applications, mesh refinement, convergence limit, and the model resistivity values set values depending on whether the data set have a value that was too high or low.

(d) Next Inversion menu was selected to initiate data inversion process.

(e) Adjustment was made by smoothing the resistivity model using the robust inversion procedure from the menu.

(f) RMS error statistics menu was selected to reduce RMS (Root Mean Square) error that affects the inversion process and the building of the model resistivity data. The resistivity data in the form of rectangular blocks (Figure 7) were modified and recalculated to produce resistivity pseudosection. This process involves a recalculation and observation of resistivity values based on pseudocross-sectional field before generating a pseudocount (calculated pseudosection) that was very similar to the actual field data. The inverse model resistivity sections were produced from pseudo count for the purpose of quantitative interpretation.

(g) After completing the inversion process, the show display menu was selected to display the actual resistivity model (Figure 8).

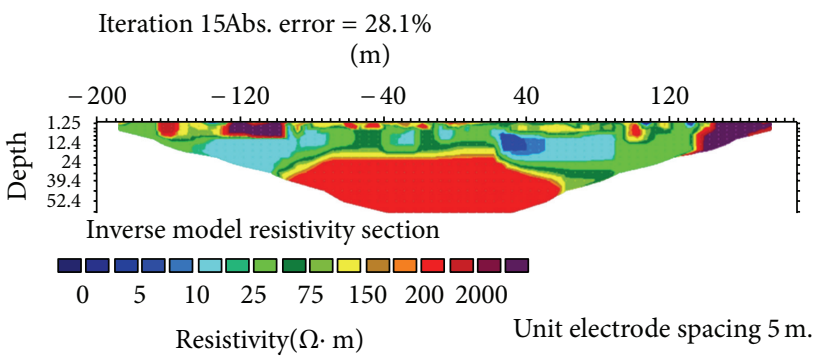

FIGURE 8: Actual resistivity model obtained from the inversion process and ready for interpretation process.

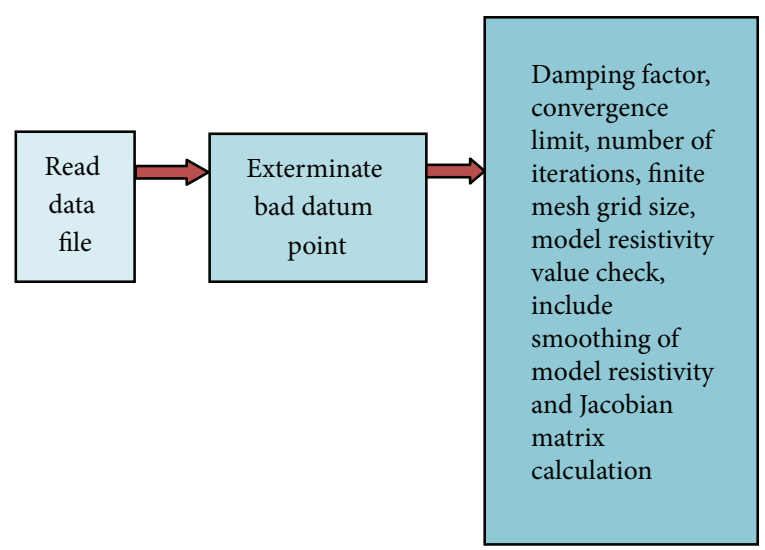

FIGURE 9: Block diagram showing fiel data processing techniques using RES2DINV software.

Interpretation of underground mass based on the followings:

(i) uniform the resistivity values for line survey because the line survey is in the same area;

(ii) underground mass is an electrical conductor which will produce a low resistivity values;

(iii) the completely weathered rock mass will produce low resistivity values;

(iv) water saturated zone will produce low resistivity values.

The data obtained from the resistivity survey profile was used to prepare an illustration model, a three-dimensional subsurface profile using AutoCAd (2009) (Figure 16).

The first stage was to build a three-dimensional topography of the initiation area, and the next stage was to build a subsurface profile in three-dimension. Data from the five lines of geoelectrical resistivity survey were combined to produce an illustration three-dimensional model of the study area.

\section{Results and Discussion}

Based on the resistivity results, a subsurface profile could be divided into four zones as shown in Table 3 below. 
TABLE 3: Attribute of various zones based on resistivity values.

\begin{tabular}{lcl}
\hline Number & $\begin{array}{l}\text { Zoning } \\
\text { symbol }\end{array}$ & Description \\
\hline 1 & a & $\begin{array}{l}\text { Resistivity values above } 5000 \Omega \mathrm{m} \text {, are the fresh } \\
\text { granite rock mass }\end{array}$ \\
2 & b & $\begin{array}{l}\text { Resistivity value between } 3000 \Omega \mathrm{m}-5000 \Omega \mathrm{m}, \\
\text { granite slightly weathering and highly fractured }\end{array}$ \\
3 & c & $\begin{array}{l}\text { Residual soil (IAEG, V-IV) } \\
(600 \Omega \mathrm{m}-3,000 \Omega \mathrm{m})\end{array}$ \\
4 & d & $\begin{array}{l}\text { Water conducting zone or high water content } \\
(<600 \Omega \mathrm{m})\end{array}$ \\
\hline
\end{tabular}

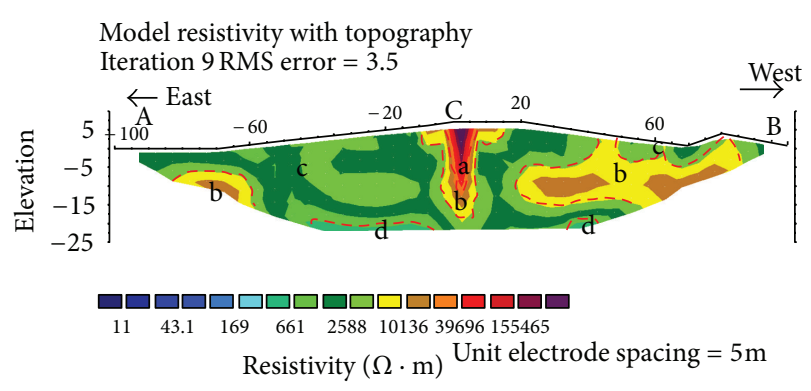

Horizontal scale is 33.97 pixels per unit spacing Vertical exaggeration in model section display $=1.1$ First electrode is located at $-100 \mathrm{~m}$ Last electrode is located at $100 \mathrm{~m}$
(a) granite $(>5,000 \Omega \mathrm{m})$
(b) weathered granite $(3000 \Omega \mathrm{m}-5,000 \Omega \mathrm{m})$
(c) residual soil $(600 \Omega \mathrm{m}-3000 \Omega \mathrm{m})$
(d) saturated soil $(<600 \Omega \mathrm{m})$

FIGURE 10: Resistivity results at line FH01.

5.1. Resistivity Line FH01. Relatively fresh granite rock that is in "zone a" has a resistivity value greater than $5,000 \mathrm{~m} \Omega$. This zone is in situ granite in the middle of the profile, at a depth of $15 \mathrm{~m}$ to $20 \mathrm{~m}$ from the original ground level.

Weathered and highly fractured granite is in "zone b" which encompasses in situ granite boulders in the middle of the profile. There are three main locations associated with it; the middle of the profile line at $\mathrm{C}$, between $\mathrm{C}$ and $\mathrm{A}$ which is at a distance of $60 \mathrm{~m}$ from the profile center line, and between $\mathrm{C}$ and $\mathrm{B}$, approximately at a distance of $20 \mathrm{~m}$ from the center (Figure 10).

The "zone c" is a zone of residual soil with resistivity values between $600 \Omega \mathrm{m}$ and $3000 \Omega \mathrm{m}$. This zone is the result of the weathering processes that change the rock into soil. Based on the geoelectrical resistivity value, high water content zone is marked as "zone d". Resistivity values recorded were less than $600 \Omega \mathrm{m}$. This zone is located between $20 \mathrm{~m}$ to $25 \mathrm{~m}$ (Figure 10).

5.2. Resistivity Line FH02. A zone of relatively fresh granite is found in the middle of the profile marked as zone a, at a depth of $20 \mathrm{~m}$ from the original ground level and with a width of $15 \mathrm{~m}$. In this zone, the resistivity value is between $5,000 \Omega \mathrm{m}$ and $45,000 \Omega \mathrm{m}$. The rock mass is surrounded by

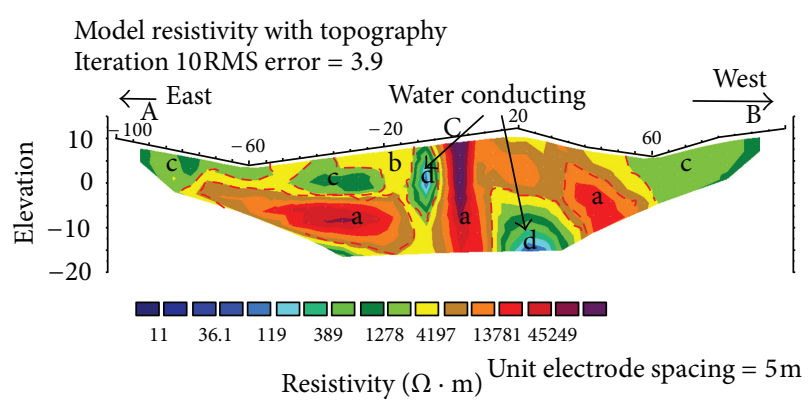

Horizontal scale is 33.97 pixels per unit spacing Vertical exaggeration in model section display $=1.1$ First electrode is located at $-100 \mathrm{~m}$ Last electrode is located at $100 \mathrm{~m}$
(a) granite $(>5000 \Omega \mathrm{m})$
(b) weathered granite and highly fractured $(3000 \Omega \mathrm{m}-5000 \Omega \mathrm{m})$
(c) residual soil $(600 \Omega \mathrm{m}-3000 \Omega \mathrm{m})$
(d) water conducting $(<600 \Omega \mathrm{m})$

FIGURE 11: Resistivity at line FH02.

a layer of weathered rock with a resistivity value between $3,000 \Omega \mathrm{m}$ to $5,000 \Omega \mathrm{m}$. There are two rock masses, which could be classified as very large boulders located at a distance of $20 \mathrm{~m}$ from the center line of the profile, to the west towards (B), at a depth of $10 \mathrm{~m}$ to $20 \mathrm{~m}$, and covered by residual soil (zone c) and the water conducting zone (zone d). The rock masses could also be found at a distance of $60 \mathrm{~m}$ to the west as well as at the eastern end of the profile (Figure 11).

The water conducting zone in the middle of the profile below the granite mass and the weathered granite zone with resistivity value of less than $600 \Omega \mathrm{m}$ is marked as "zone d" (Figure 11).

The subsurface conditions are relatively heterogeneous; weathered and highly fractured granite with water containing zone was located below it. Therefore the rock mass above this water containing zone is prone to failure (see, e.g., Figure 20).

5.3. Resistivity Line FH03. Zone a, which is a relatively fresh granite rock mass is clearly visible at the center $\mathrm{C}$, and at a distance of $20 \mathrm{~m}$ east from center $\mathrm{C}$, at a depth of $10 \mathrm{~m}$. The rock mass is surrounded by layers of zone $b$ weathered rock, and "zone c" residual soil. The rock mass could be classified as in situ granite between $\mathrm{C}$ and $\mathrm{A}$ and is covered with residual soil (zone c), together with weathered and fractured granite (Figure 12).

The zone with high water content detected in lines FH02 and FH01 is at a greater depth at this location and remains undetected because the penetration depth of imaging is insufficient.

5.4. Resistivity Line FH04. Four main zones that are probably water conducting were detected. The "zone d" has a low resistivity value of below $100 \Omega \mathrm{m}$. The water conducting zone is within the residual soil (zone c) and the granite rock which is probably highly fractured and weathered. The weathered granite zone is at a depth of between $0 \mathrm{~m}$ to $5 \mathrm{~m}$. Relatively 


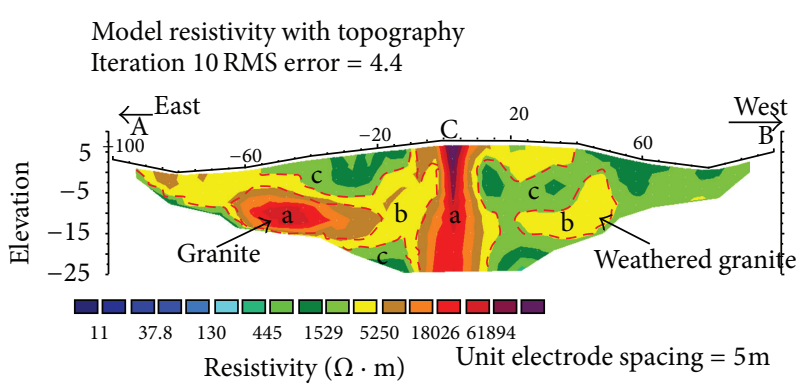

Horizontal scale is 33.97 pixels per unit spacing

Vertical exaggeration in model section display $=0.92$

First electrode is located at $-100 \mathrm{~m}$

Last electrode is located at $100 \mathrm{~m}$

(a) granite $(>5000 \Omega \mathrm{m})$

(b) weathered granite and highly fractured $(3000 \Omega \mathrm{m}-5,000 \Omega \mathrm{m})$

(c) residual soil $(6000 \Omega \mathrm{m}-3000 \Omega \mathrm{m})$

FIGURE 12: Resistivity result at line FH03.

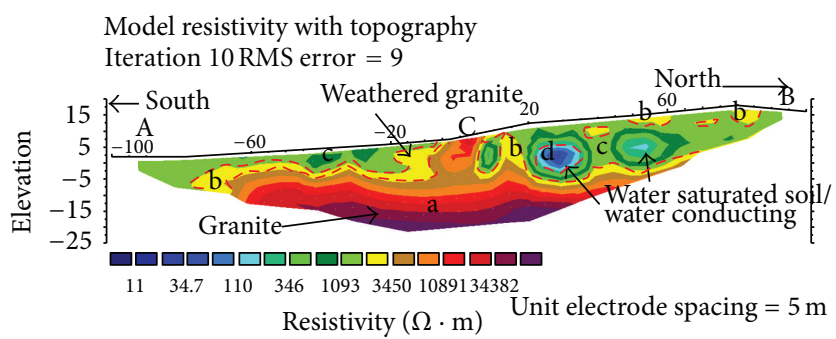

Horizontal scale is 33.97 pixels per unit spacing

Vertical exaggeration in model section display $=0.92$

First electrode is located at $-100 \mathrm{~m}$

Last electrode is located at $100 \mathrm{~m}$

(a) granite $(>5000 \Omega \mathrm{m})$

(b) weathered granite and highly fractured $(1200 \Omega \mathrm{m}-5000 \Omega \mathrm{m})$

(c) residual soil $(100 \Omega \mathrm{m}-1200 \Omega \mathrm{m})$

(d) water conducting $(<100 \Omega \mathrm{m})$

FIgURE 13: Resistivity line at FH04.

fresh granite rock with resistivity values between $5,000 \Omega \mathrm{m}$ to $34,500 \Omega \mathrm{m}$ occurs at a depth of $10 \mathrm{~m}$ below the original ground level. Granite rock is also found on the surface at the center line of the profile at C (Figure 13).

The whole subsurface at a depth between $0 \mathrm{~m}$ to $5 \mathrm{~m}$ is composed of weathered granite, residual soil, and a water conducting zone. This layer is very weak because the rock is weathered and highly fractured with soil having high water content. Therefore, this layer is very weak and the complete mass can be considered as highly unstable.

5.5. Resistivity Line FH05. The subsurface is relatively heterogeneous, with layering of residual soil (zone c), and weathered and fractured granite (zone b) as well as fresh granite (zone a). Water conducting zones are detected at the center of the profile at $\mathrm{C}$, between $5 \mathrm{~m}$ to $10 \mathrm{~m}$ deep.

Furthermore, a water conducting zone is detected below the relatively fresh granite between C and B (Figure 14).

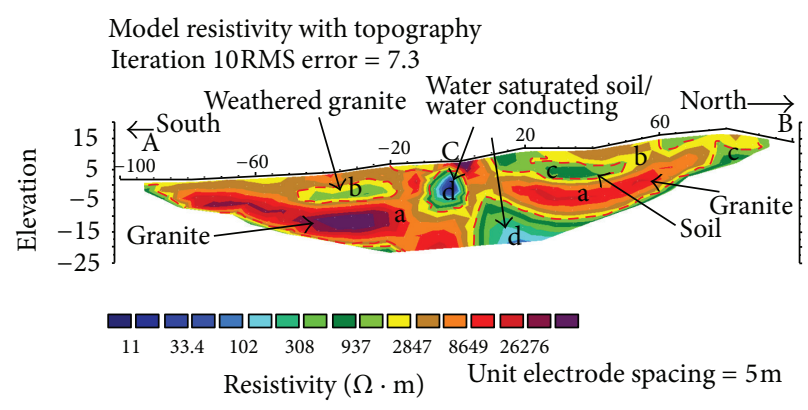

Horizontal scale is 33.97 pixels per unit spacing

Vertical exaggeration in model section display $=0.92$

First electrode is located at $-100 \mathrm{~m}$

Last electrode is located at $100 \mathrm{~m}$

(a) granite $(>5000 \Omega \mathrm{m})$

(b) weathered granite and highly fractured $(3000 \Omega \mathrm{m}-5000 \Omega \mathrm{m})$

(c) residual soil $(600 \Omega \mathrm{m}-3000 \Omega \mathrm{m})$

(d) water conducting $(<600 \Omega \mathrm{m})$

FIGURE 14: Resistivity result at line FH05.

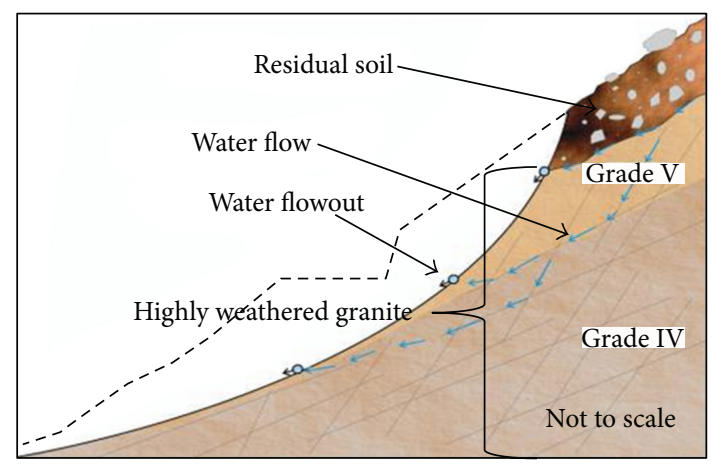

FIgURE 15: A hypothetical cross-section at the main scarp.

Hence, the granite is virtually "floating" above the water conducting zone and therefore could be considered unstable.

5.6. Discussion. The subsurface conditions are visualized in Figure 17. At the surface, exposed boulders could be found, and, by observing the surface of the main failure mass found at the location, highly weathered granitic rock is determined. The residual layer is relatively thin at this zone where weathered granite dominates the slope face of failure mass. Below this in situ granite mass, a water conducting zone with an approximate thickness of $20 \mathrm{~m}$ is detected.

This water flows out at the lower part of the slope (Figures 15 and 17) at a rate of $43 \mathrm{cc} / \mathrm{sec}$ and is a main causative factor for this debris flow. An illustration subsurface model view of the subsurface conditions is shown in Figure 17. A hypothetical cross-section of the failed slope is shown in Figure 15 and the interpretative geological profile and seepage within that slope. The underground water flow and seepage through the fractured and highly weathered granite mass are the main causative factor for this debris flow. Figure 23 shows 


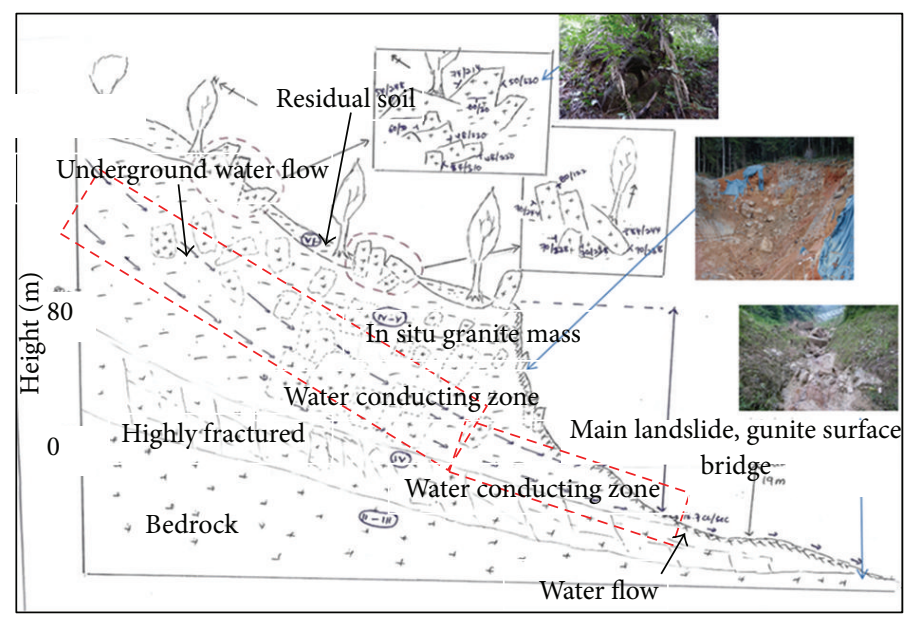

FIGURE 16: Conceptual sketch showing the subsurface profile at the initiation area of the debris flow.

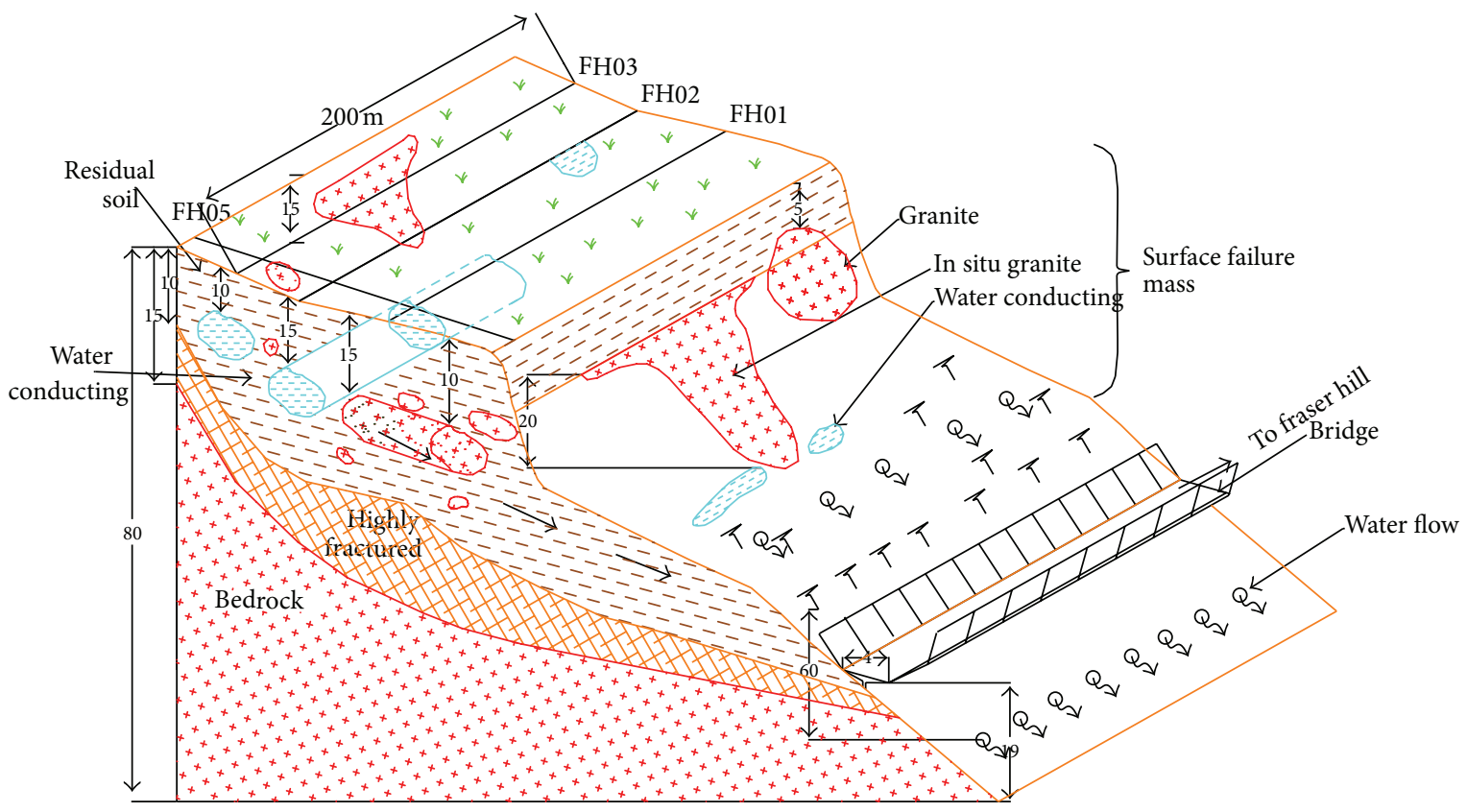

FIgURE 17: Postulated subsurface conditions at initiation zone of debris flow.

the water seepage along the boundary of the two different geological materials and a close view of the main failure scarp, exposing the unconformable contact between the overlying residual soil and the underlying weathered granite. Figure 24 is an on-site view of initiation zone of the study area (see Figure 21 for a general view). A combination of surface and subsurface geological data (geoelectrical resistivity) were used to produce illustration in three-dimensional model as shown in Figure 12.

Thirteen (13) Mackintosh Probe tests were conducted in the initiation debris flow zones and flow paths zones. Mackintosh Probe resulted in that the residual soil was between 1.20 meters to 3.00 meters thick with value of 100 blows (Table 4). That location of Mackintosh probe tests is shown in Figure 3.
This method is suitable to determine the flow of the groundwater in the initiation zone by the characteristics as shown below:

(i) initiation of a steep slope,

(ii) seepage at the slope surface and toe of the slope,

(iii) low intensity of rainfall before and during debris flow incident,

(iv) material consisting of residual soils and weathered rock.

\section{Conclusion}

This rock mass within the initiation zone of the debris flow is a heterogeneous mass of fresh, moderately weathered, and 


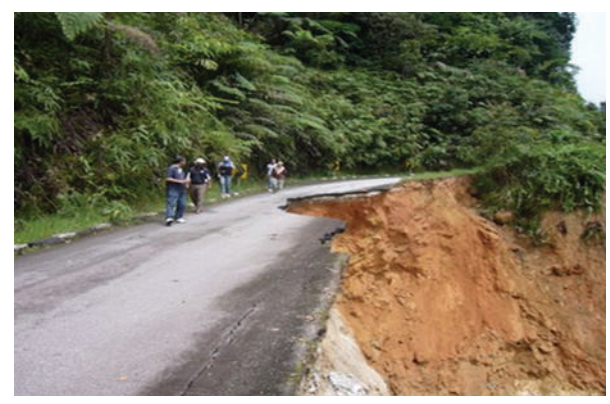

FIGURE 18: The first landslide, photo taken on Jan 19, 2008, at Fraser's Hill Gap road (FT 148).

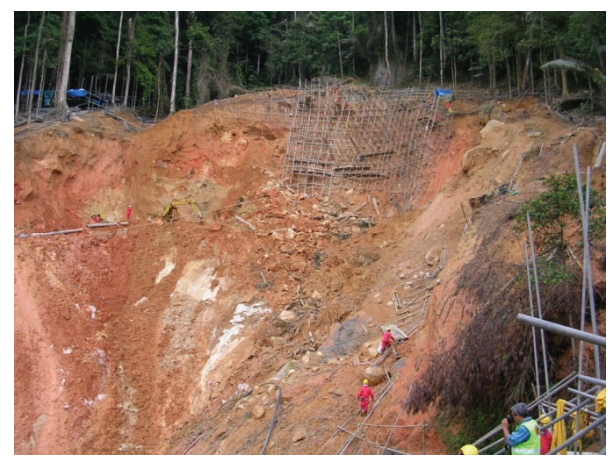

FIGURE 19: View of the final landslide before strengthening of slope was carried out.

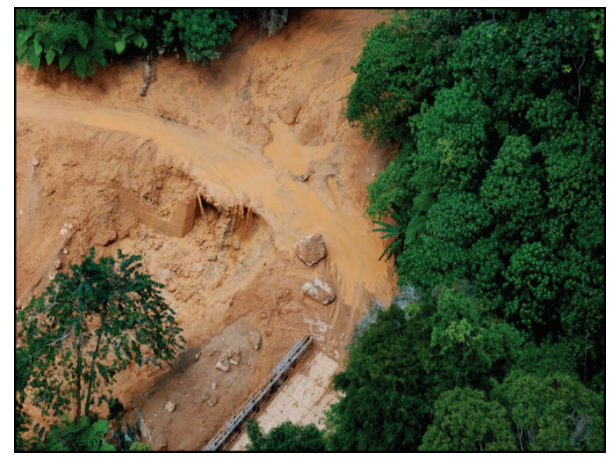

FIGURE 20: The view of conditions at FT 055, Tranum-Gap road, near a Bailey Bridge on March 28, 2008.

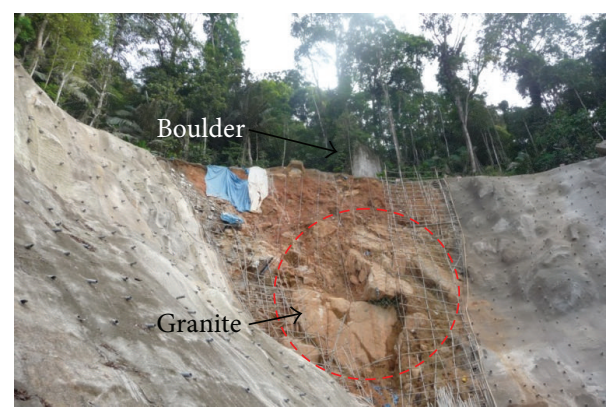

FIGURE 21: General view of initiation zone during geoelectrical resistivity survey.

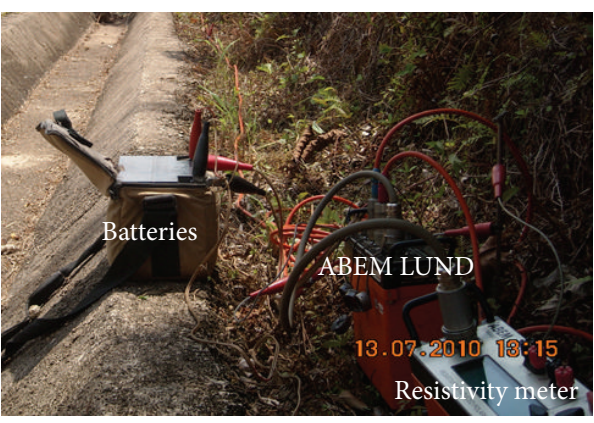

FIgURE 22: The ABEM SAS1000 resistivity meter and ABEM LUND ES464 electrode selector system.

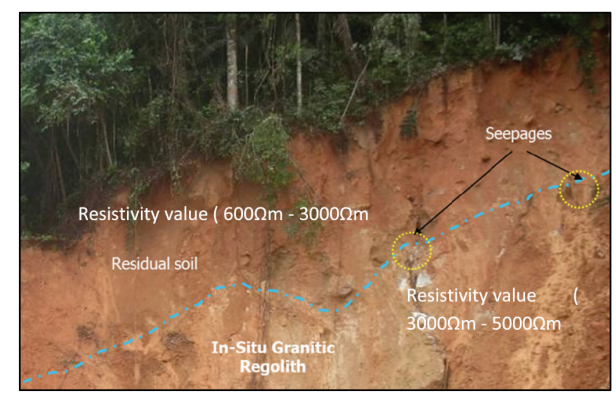

FIGURE 23: Boundary of residual soil and weathered granite at the main scarp.

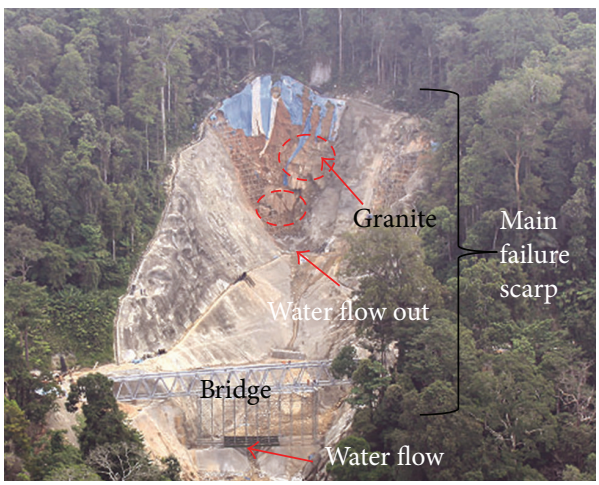

FIGURE 24: View of main failure scarp or initiation area of debris flow at Fraser's Hill.

highly fractured granite with residual soil together with a water conducting zone at a depth below the in situ granite. The geoelectrical resistivity profiling revealed that the granite rock mass is virtually "floating" above the water conducting zone and is therefore highly unstable. In conclusion, the groundwater flow is identified as a weak zone or a plane of weakness. Determination of the position of the groundwater flow and subsurface profile is very important in designing slope strengthening and reinforcement works in this area. 
TABle 4: Mackintosh Probe result.

\begin{tabular}{lcc}
\hline MP number & Depth with 100 blows & Remarks \\
\hline 5 & 2.10 & Flow path \\
6 & 2.10 & Flow path \\
7 & 3.00 & Initiation zone \\
8 & 3.00 & Initiation zone \\
9 & 2.10 & Initiation zone \\
10 & 1.20 & Initiation zone \\
11 & 2.70 & Initiation zone \\
12 & 3.00 & Initiation zone \\
13 & 2.10 & Flow path \\
14 & 2.40 & Flow path \\
15 & 2.70 & Flow path \\
16 & 3.30 & Flow path \\
17 & 0.60 & Flow path \\
\hline
\end{tabular}

\section{Acknowledgments}

The authors would like to thank Slopes Engineering Branch, Public Works Department, Malaysia, for the support in conducting this study and both reviewers for their constructive comments.

\section{References}

[1] J. Stiny, Die Muren, Verlag der Wagner' Schen UniversitaetsBuchhandlung, Innsbruck, Austria, 1910, Translated by M. Jakob and N. Skermer, Debris Flows, EBA Engineering Consultants, Vancouver, Canada, 1997.

[2] C. F. S. Sharpe, Landslides and Related Phenomena, Columbia University Press, New York, NY, USA, 1938.

[3] O. Hungr, S. G. Evans, M. J. Bovis, and J. N. Hutchinson, "A review of the classification of landslides of the flow type," Environmental and Engineering Geoscience, vol. 7, no. 3, pp. 221$238,2001$.

[4] O. Hungr, S. G. Evans, M. J. Bovis, and J. N. Hutchinson, "A review of the classification of landslides of the flow type," Environmental and Engineering Geoscience, vol. 7, no. 3, pp. 221238, 2001.

[5] M. Jakob, "A size classification for debris flows," Engineering Geology, vol. 79, no. 3-4, pp. 151-161, 2005.

[6] R. M. Iverson, M. E. Reid, and R. G. LaHusen, "Debris-flow mobilization from landslides," Annual Review of Earth and Planetary Sciences, vol. 25, pp. 85-138, 1997.

[7] C. S. Hutchinson and D. N. K. Tan, Geology of Peninsular Malaysia, Geological Society of Malaysia, Kuala Lumpur, Malaysia, 2009.

[8] V. Chiessi, M. D’Orefice, and S. Superbo, "Geophysical surveying of slopes affected by debris flows: the case of S. Felice a Cancello (Caserta, Southern Italy)," Annals of Geophysics, vol. 46, no. 6, pp. 1283-1295, 2003.

[9] D. Jongman and S. Garambois, "Geophysical investigation of landslide: a review," Bulletin de la Societe Geologique de France, vol. 178, no. 2, pp. 101-112, 2007.

[10] S. S. Hubbard and N. Linde, "Hydrogeophysics," in Treatise on Water Science, P. Wilderer, Ed., vol. 1, pp. 401-434, Academic Press, Oxford, UK, 2011.
[11] D. H. Griffiths and R. D. Barker, "Two-dimensional resistivity imaging and modelling in areas of complex geology," Journal of Applied Geophysics, vol. 29, no. 3-4, pp. 211-226, 1993.

[12] M. H. Marjani, Geology and engineering geology at Fraser's Hill, Pahang Darul Makmur [Thesis], Universiti Kebangsaan Malaysia, 2005. 

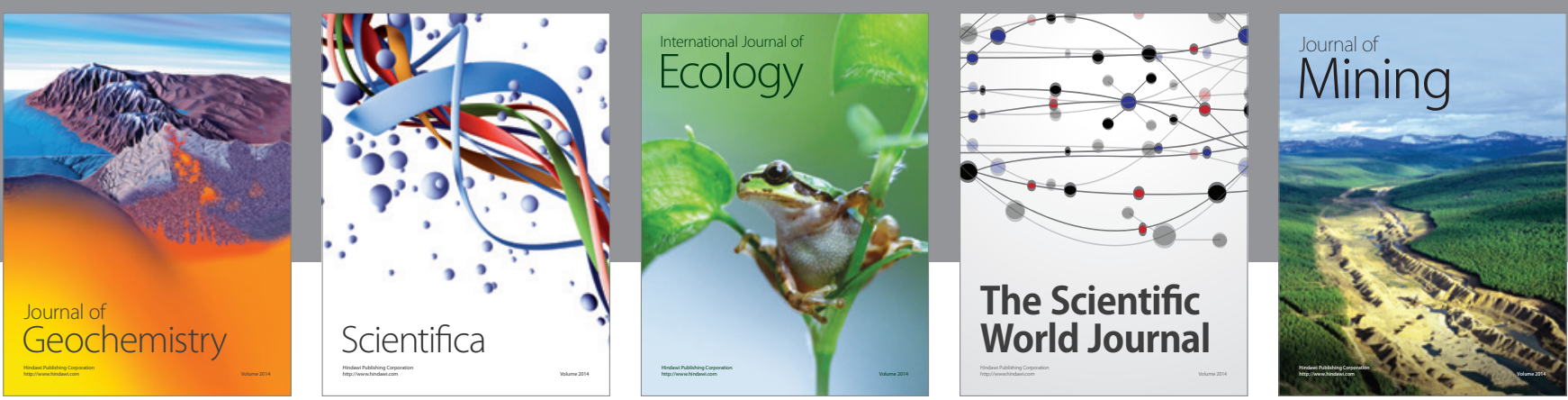

The Scientific World Journal
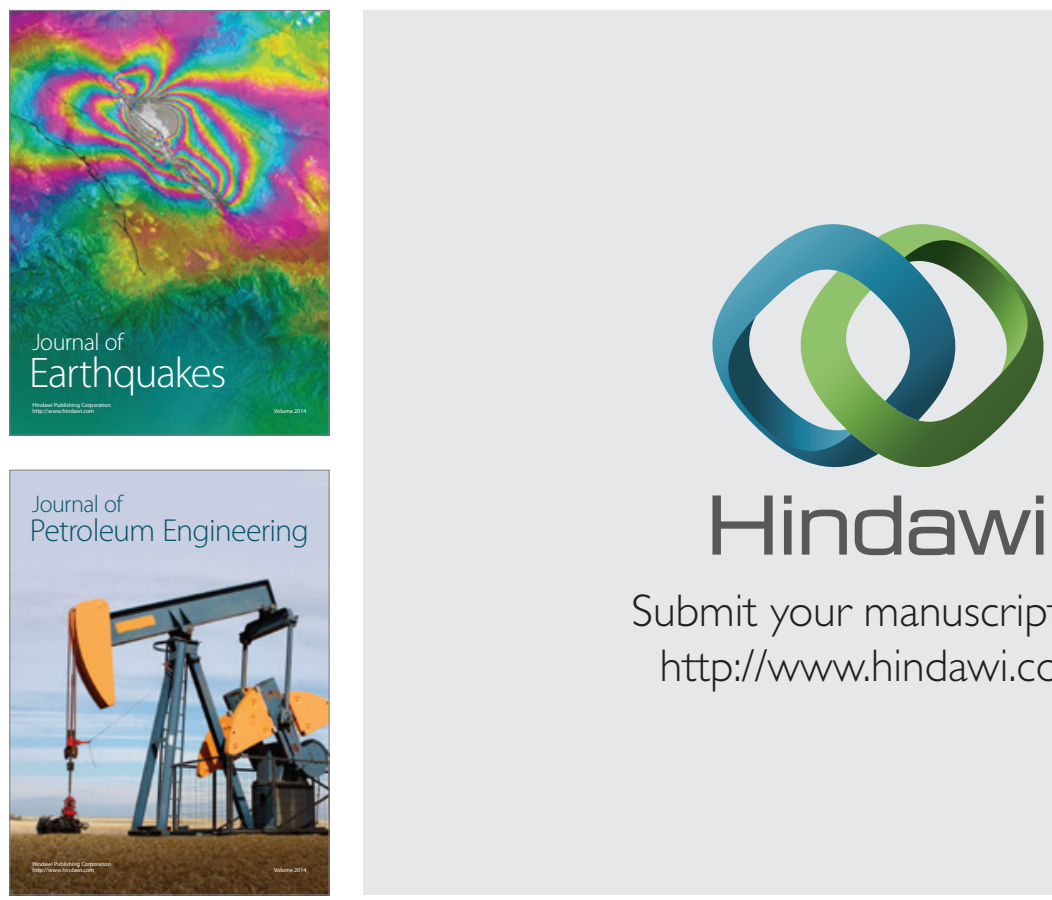

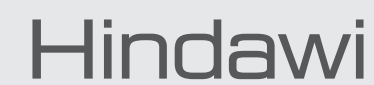

Submit your manuscripts at

http://www.hindawi.com
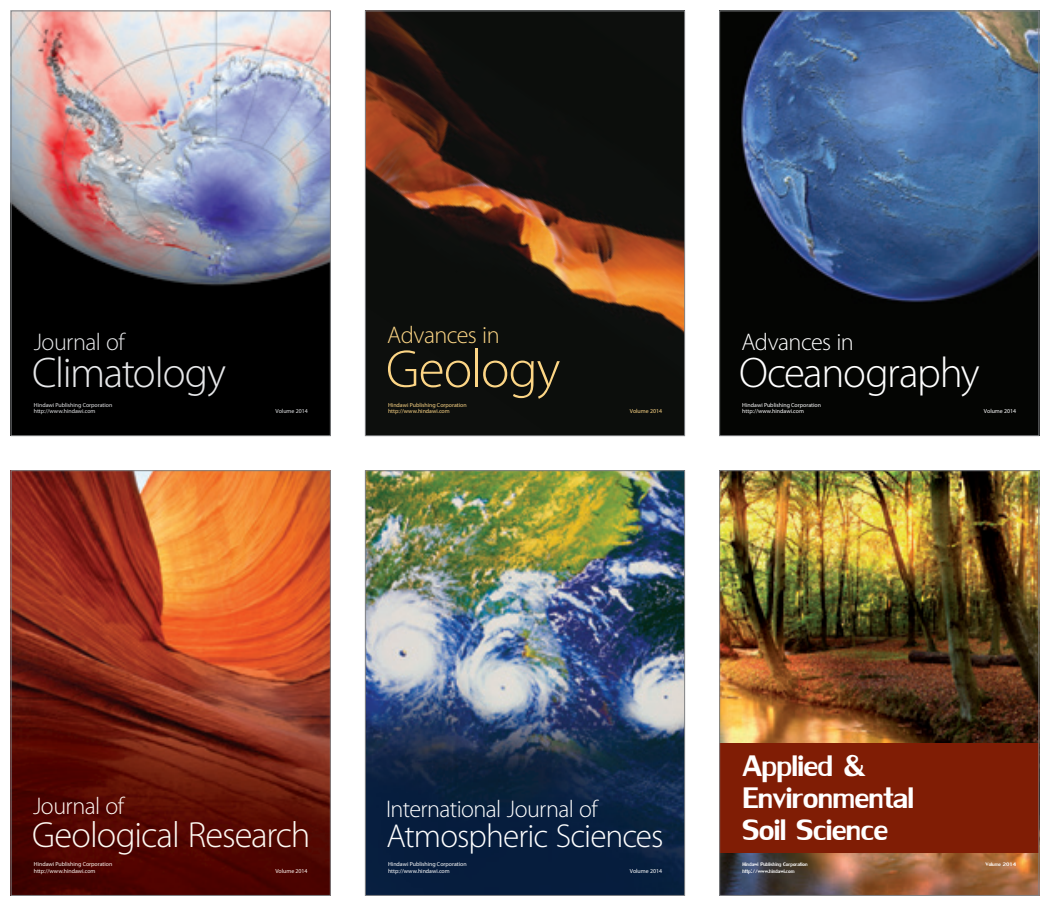
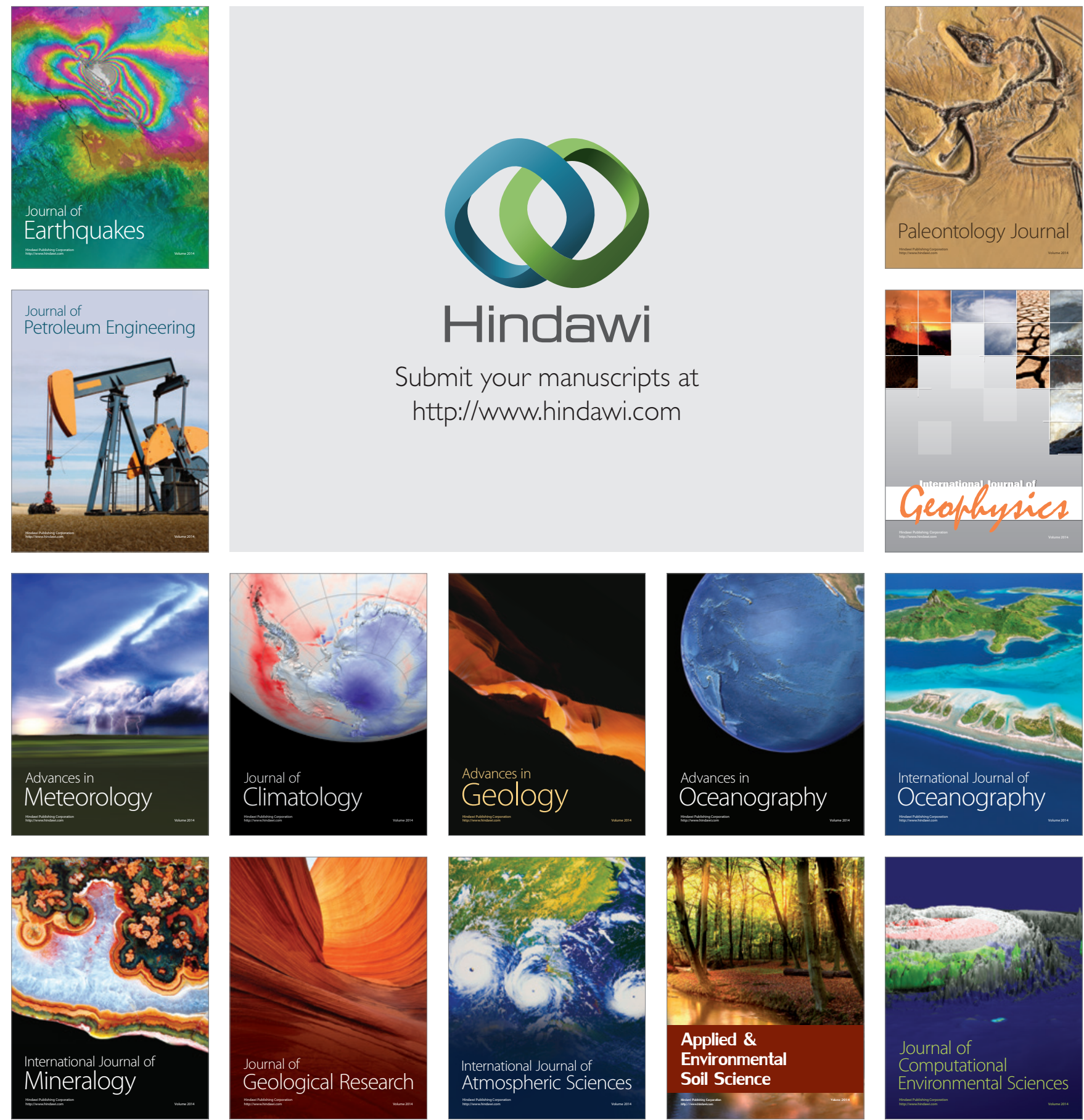